\title{
水平気流中に置かれた垂直加熱平板まわりの強制-自然 直交流共存対流の流動と伝熱*
}

\author{
光石 娔 彦*1, 酒 井 晃*2 \\ 北 村 健 三*1, 三角 利 之草
}

\section{Fluid Flow and Heat Transfer of Combined Convection Adjacent to Vertical} Heated Plates Placed in Uniform Horizontal Flow of Air

Akihiko MITSUISHI*4, Akira SAKAI,

Kenzo KITAMURA and Toshiyuki MISUMI

${ }^{* 4}$ Department of Mechanical Engineering, Toyohashi University of Technology,

1-1 Hibarigaoka, Tempaku-cho, Toyohashi-shi, Aichi, 441-8580 Japan

Experiments have been carried out for combined convective flows of air adjacent to the vertical heated plates in the uniform horizontal forced flows to investigate relationships between the flow and the heat transfer. The experiments cover the ranges of the Reynolds and modified Rayleigh numbers as; $R e_{L}=160-2300$ and $R a_{1}^{*}=4.3 \times 10^{5}-2.0 \times 10^{8}$. The flow fields over plates are visualized with particles and smoke. The results show that the stagnation point moves downward away from the center of the plates when the surface heat flux is beyond a critical value. The condition where the stagnation point begins to move is expressed with the non-dimensional parameters as; $G r_{L}^{*} / \operatorname{Re}_{L}^{2.5}=$ 0.15 . Profiles of measured local heat transfer coefficients are smooth even at the stagnation points in all cases examined. When the buoyancy effect is sufficiently weak, the coefficients agree well with those of the wedge flow. With increasing the surface heat flux, the coefficients are augmented to approach asymptotically the boundary layer solution of natural convection along a vertical heated plate. Finally, forced, natural and combined convective flow regimes are classified by the nondimensional parameter $\left(G r_{L}^{*} / \operatorname{Re}_{L}^{2.5}\right)$.

Key Words: Heat Transfer, Natural Convection, Forced Convection, Vertical Plate, Flow Visualization

\section{1. 緒言}

図 1 に示すように, 一様かつ水平に流れる気流に直 交して有限な大きさの加熱平板が置かれ, 平板から気 流に向かって熱が移動する体系は，様々な伝熱機器・ 装置あるいは我々の身近で遭遇する流れのひとつであ る.この体系下で気流の流速が十分大きければ，平板 からの伝熱はいわゆる強制対流くさび流れ (Wedge flow）あるいは Hiemenz flow の伝熱問題として取り扱 える. 一方, 平板が強く加熱され, 流速が相対的に遅 い場合には, 浮力の影響が無視できなくなり, 強制対 流と自然対流が共存した，いわゆる共存対流あるいは 複合対流と呼ばれる流れが出現する.このような体系 での共存対流に関しては, 最近とくに横型常圧熱 CVD 炉内に垂直に装荷されたシリコンウエハ上に各種の機 能性薄膜を蒸着する場合などで問題となる流れであり， ウエ八上に均一な成膜を実現する上で，ウエハまわり の流動・伝熱特性の把握が喫緊の課題となっている. しかし，このような垂直平板まわりの共存対流の流動 と伝熱に関しては, 著者らの知る限り, Ramachandran

* 原稿受付 2008 年 4 月 28 日.

*1 正員, 豊橋技術科学大学機械システム工学系(严 441-8580 豊橋市天伯町雲雀ヶ丘 1-1).

*2 豊橋技術科学大学機械システム工学系.

*3 正員, 鹿児島工業高等専門学校機械工学科(丞 899-8150 霧 島市隼人町真孝 1350-1).

E-mail : mituisi@mech.tut.ac.jp
ら (1)が平板まわりに発達する層流くさび流れに浮力の 効果を取り入れた解析を試みた例が唯一挙げられるだ けである. 彼らの解析は，等温あるいは等熱流束加熱 された垂直な無限平板に，一様かつ水平に流れる空気 流が直角に衝突する場合を対象としたものである．彼 らは，平板に衝突する強制対流の岐点を基準として， この岐点より上方側では, 浮力は流れを加速する方向 に作用することから並行流（Aiding flow），一方，岐 点より下方側では浮力は流れを減速する方向に作用す ることから対向流（Opposing flow）とみなし，平板表 面に沿う層流くさび流れの速度および温度場を相似変 数法により解析したものである. その結果, 岐点より 上方の並行流域では, 浮力の増加に伴って流れが加速 され，熱伝達率は強制対流くさび流れの值より高くな

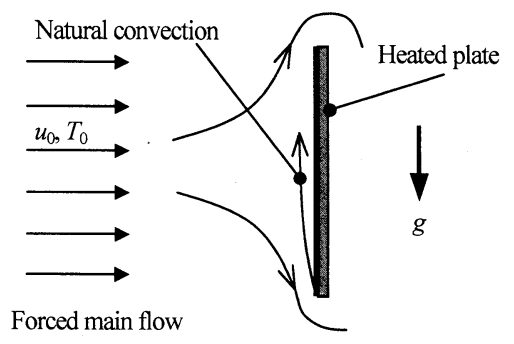

Fig. 1 Present flow configuration 
り,逆に岐点より下方の対向流域では流れが減速され， 低くなる結果を得ている。しかし，彼らの解析は，強 制対流くさび流れに浮力が付加的に作用する場合を対 象としたもので, 後述するように, くさび流れの岐点 が浮力によって移動する場合，あるいは更に浮力が強 くなり，平板全体が上向きの自然対流に覆われる場合 には適用できないことは明らかである.

この他に, 本研究に関連する研究として, 水平に流 れる管内流中に加熱角柱を水平に設置した場合につい て，角柱まわりの共存対流を数值解析により調べた Biswas $ら^{(2)}$, Turki $ら^{(3)}$, Dhiman $ら^{(4)}$ の研究が挙げられ る.これらの解析は, いずれも流れを層流二次元と仮 定して, 等温加熱された正方形角柱まわりの速度およ び温度場を解いたもので, 角柱高さ $H$ 基準のレイノル ズ数 $R e_{H}$ が最大でも 200 以下 ${ }^{(3)}$, 浮力と慣性力の比を 表すリチャードソン数 $R i_{H}\left(=G r_{H} / R e_{H}^{2}\right)$ が最大でも 1 以下 ${ }^{(4)}$ の, レイノルズ数が低くかつ浮力の影響が相対 的に小さな領域を対象としている. また，これらの解 析では, 角柱背後に生じる後流に対して浮力が如何な る影響を及ぼすかという問題に主たる関心があったた め, 角柱近傍の流動や角柱各表面での局所伝熱特性等 については, 詳しい議論がなされていない.

以上の研究の現状を考えると, 本研究で取り扱う垂 直加熱平板まわりの共存対流に関しては, その基本と なる流動・伝熱特性自体が依然として不明のままであ る.これを明らかにするには，平板上にどのような流 れが生じるか調べることが必要不可欠と思われる。 そ

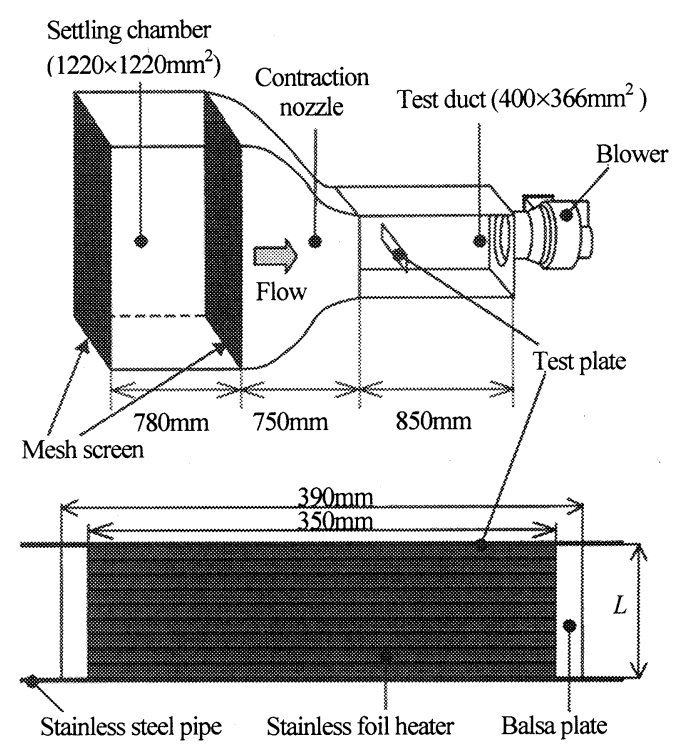

Fig. 2 Experimental apparatus
こで本研究では，まず流れの可視化を試み，平板まわ りの流れの詳細を把握することにした. ついで平板の 局所熱伝達率を測定し, 平板まわりの流れと局所伝熱 特性との関連を探ることにした. 試験流体には常温の 空気を, また試験平板には比較的小さな等熱流束加熱 平板を用いて，平板上に層流くさび流れが実現される 強制対流支配域から，平板全体が鉛直上向きの流れで 覆われる自然対流支配域に至る広範な領域について, 系統的な可視化および伝熱実験を遂行することにした. 本研究は垂直加熱平板に直交して一様な強制対流が 衝突する体系下での共存対流の流動, 伝熱特性につい て基本的な理解を得ることを主目的としたものである が, 本研究で得た一連の成果は, 上述した熱 CVD 炉 内における成膜問題や, 日射を受けた建物, あるいは 椂々な発熱物体まわりの伝熱問題などに対して, 有益 な資料を提供するものと考えられる.

\section{2. 実験装置およひ測定}

本研究で用いた実験装置の構成および寸法諸元を図 2 に示す. 装置は水平に設置された吸込型小型風洞, および試験平板から成り立っている. 実験室内の空気 は, この風洞の整流同端部から吸い込まれ, メッシュ および縮流ノズルにより一様かつ低乱れ度の流れに整 流された後, 断面積 $400 \times 366 \mathrm{~mm}^{2}$, 長さ $850 \mathrm{~mm}$ の試験 ダクト内に流入し, ブロワーにより実験室内一排出さ れる. 試験平板は, 厚さ $2 \mathrm{~mm}$, 幅 $390 \mathrm{~mm}$ のバルサ板 2枚を $2 \mathrm{~mm}$ 厚のスペーサを介して貼り合わせた構造と なっており, バルサ板の間陌には空気が満たされてい る. この試験平板の片側表面には厚さ $30 \mu \mathrm{m}$ のステン レス箔ヒータを貼り付け, 交流を通電することにより 等熱流束条件で加熱した. また, 裏面には厚さ $20 \mathrm{~mm}$ の発泡スチロール製断熱板を接着し, 平板裏面側への 熱伝導損失を防止している. 実験には, 長さ $L=50,100$, $150 \mathrm{~mm}$ の 3 種類の試験平板を製作, 使用した. この試 験平板の加熱面側を主流と直交するよう, 試験ダクト 内に垂直に設置した.この試験平板のスパン方向中心 線上の箔ヒ一夕裏面に, 鉛直方向に所定の間隔で径 $100 \mu \mathrm{m} の \mathrm{~K}$ 型熱電対をスポット溶接し, 局所壁温 $T_{w x}$ を測定した. なお，空気の実験では対流伝熱量に比し て, ヒータ表面からの放射熱損失が無視できない可能 性がある. そこで，この放射熱流束 $q_{r}$ を無限空間への 放射を仮定し, 次式により求めた。

$$
q_{r}=\varepsilon \sigma\left(T_{w x}{ }^{4}-T_{0}{ }^{4}\right)
$$

ここで, $\sigma$ はステファン・ボルツマン定数であり， $\sigma=$ $5.67 \times 10^{-8} \mathrm{~W} / \mathrm{m}^{2} \mathrm{~K}^{4}, \varepsilon$ は平板表面の放射率であり, 予め 検定したステンレス䇴の放射率 $\varepsilon=0.16$ を採用した. 
また, $T_{0}$ は強制対流主流の温度であり, 縮流ノズル出 口部に設置した熱電対により測定した. そして, ヒー 夕の発熱量から放射損失量を差し引くことにより, 対 流熱流束 $q_{w}$ を算出した. この対流熱流束 $q_{w}$ をもとに, 局所熱伝達率 $h_{x}$ を次式で定義した.

$$
h_{x}=q_{w} /\left(T_{w x}-T_{0}\right)
$$

平板のまわりを流れる強制対流主流の流動状況を可 視化するために，ステアリン酸マグネシウム粉末（キ シダ化学, 平均粒径 $75 \mu \mathrm{m}$ ）を気流中に浮遊させ, 粒 子の軌跡を写真撮影した. また, 併せて加熱面近傍の 流れを線香の煙により可視化した. この煙は，上述の 箔ヒータの隙間に設けた数箇所のスリットから流出さ せた. 実験は, 強制対流主流流速 $u_{0}$ およひ平板長さ $L$

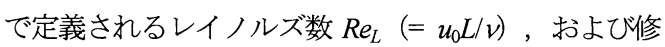
正レイリー数 $R a_{L}\left(=g \beta q_{w} L^{4} / \lambda \alpha v\right)$ を,それぞれ $160<R e_{L}$ $<2300,4.3 \times 10^{5}<R a_{L}^{*}<2.0 \times 10^{8}$ の範囲で変化させた場 合について行った. なお, 後述する無次元数中の物性 值は膜温度 $T_{f}\left(=\left(T_{w x}+T_{0}\right) / 2\right)$ で評価し, 体膨張率 $\beta$ の み $1 / T_{0}$ で評価した。

\section{3. 実験結果および考察}

$3 \cdot 1$ 流れの可視化 まず平板まわりにどのよ うな流れが生じるか，ステアリン酸マグネシウム粒子 をトレーサとした可視化により調べてみた。 その代表 的な結果を, 平板長さ $L=100 \mathrm{~mm}$, 強制対流主流流速 $u_{0}=0.09 \mathrm{~m} / \mathrm{s}$ の場合について図 3 に示寸.この図は平板 のスパン方向中心線上にスリット光を照射し，平板側 方から流れを写真撮影したものであり，強制対流主流 は図の左側から右に向かって一様な流速で流れ込んで いる. 図の上下端は試験平板の上下端と一致する。 ま
ず図 3(a)に示す非加熱平板の結果であるが，強制対流 主流は平板中央で平板上端へ向かう流れと下端へ向か う流れに分岐している.これより岐点は平板中央に存 在し，平板上には層流くさび流れが生じていることが わかる.つぎに, 試験平板を熱流束 $q_{w}=15 \mathrm{~W} / \mathrm{m}^{2}$ で加 熱した場合であるが, 図 3(b)から, 平板中央付近を流 れる粒子は平板に衝突する前に一旦下降した後, 図中 矢印で示した地点付近で分岐し，この矢印よりも上方 の粒子は平板表面に沿って上昇, 下方の粒子は下降し ていく様子が読み取れる.この結果より, 流れの岐点 は平板中央よりも下方に位置することがわかる.さら に熱流束を $50,100,150 \mathrm{~W} / \mathrm{m}^{2}$ と増加させていくと, こ の岐点の位置は図 3(c) (e)中の矢印で示すように, 平 板下方へと順次移動していく.これに伴って, 平板近 傍では鉛直上方に向かう流れが次第に卓越するように なり, 平板中心に対して上下非対称な流れ場が形成さ れる.

上述した岐点の移動をさらに詳しく調べるために, 煙を試験平板の下半部数箇所の位置に設けたスリット から流出させ, 煙の流れる方向を可視化観察してみた. その代表例として, 図 3 と同じ条件下で実験を行った 結果を図 4 に示す. ここで, 図 4 中の矢印は煙の流出 位置を示しており, 平板中心からの距離を併記してい る, まず，平板を加熱しない図 4(a)の結果であるが, 平板中心から $5 \mathrm{~mm}$ 下方に設けたスリットから煙を流 出させると, 煙は平板表面に沿ってそのまま鉛直下方 に流れていくことがわかる.これは図 3(a)で示したよ うに, 非加熱平板では岐点が平板中心にあることに因 る.つぎに, 熱流束を $q_{w}=25 \mathrm{~W} / \mathrm{m}^{2}$ に増加させると, 図4(b)に示すように，平板中央から $27 \mathrm{~mm}$ 下方のスリ

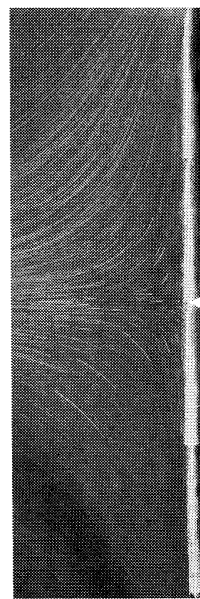

(a) $q_{w}=0 \mathrm{~W} / \mathrm{m}^{2}$

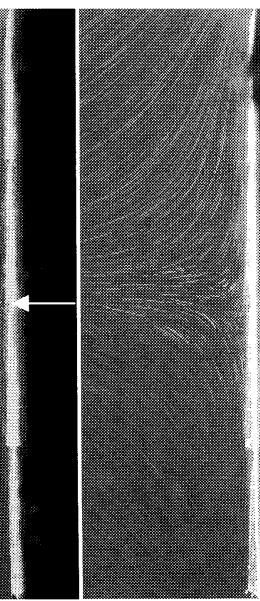

(b) $q_{w}=15 \mathrm{~W} / \mathrm{m}^{2}$

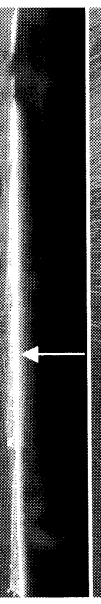

(c) $q_{w}=50 \mathrm{~W} / \mathrm{m}^{2}$

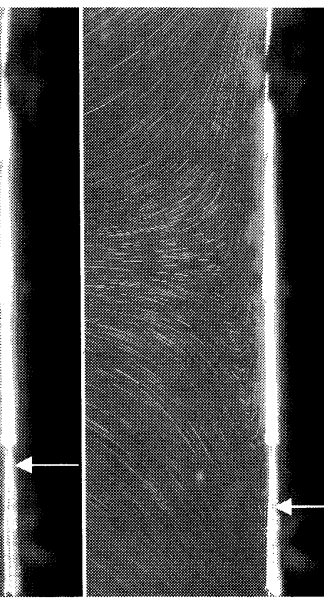

(d) $q_{w}=100 \mathrm{~W} / \mathrm{m}^{2}$

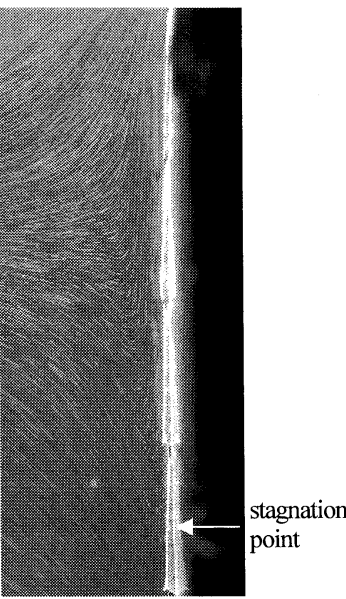

(e) $q_{w}=150 \mathrm{~W} / \mathrm{m}^{2}$

Fig. 3 Visualized flow fields over a heated plate $\left(L=100 \mathrm{~mm}, u_{0}=0.09 \mathrm{~m} / \mathrm{s}\right)$ 


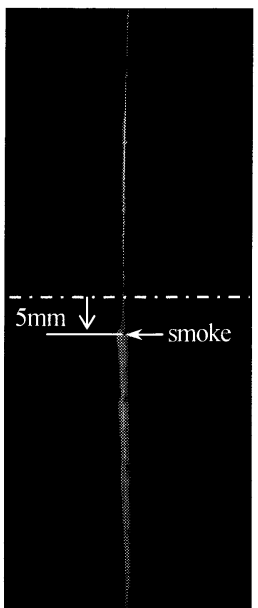

(a) $q_{w}=0 \mathrm{~W} / \mathrm{m}^{2}$

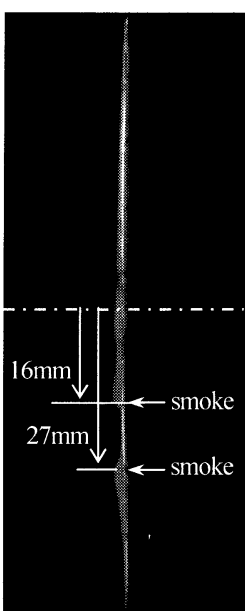

(b) $q_{w}=25 \mathrm{~W} / \mathrm{m}^{2}$

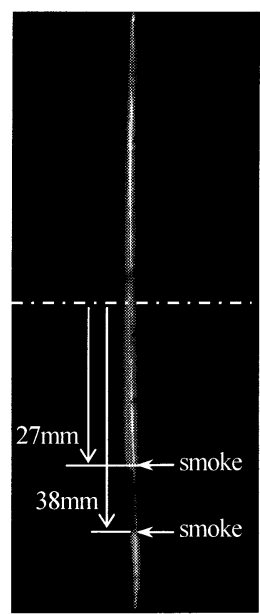

(c) $q_{w}=50 \mathrm{~W} / \mathrm{m}^{2}$

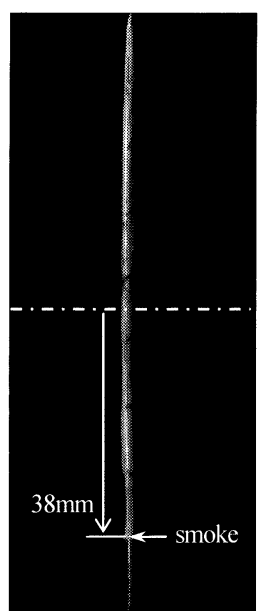

(d) $q_{w}=150 \mathrm{~W} / \mathrm{m}^{2}$

Fig. 4 Visualization of the position of the stagnation point $\left(L=100 \mathrm{~mm}, u_{0}=0.09 \mathrm{~m} / \mathrm{s}\right)$

ットから流出した煙は下方へ流れるのに対し，16mm 下方のスリットから出た煙は鉛直上方に向かって流れ ている.この結果から, 岐点は平板中心から 16〜27mm の位置に存在していることがわかる.ささらに熱流束を $q_{w}=50,150 \mathrm{~W} / \mathrm{m}^{2}$ に増加させると，岐点は図 4(c), (d)に 示すように，平板中心からそれぞれ 27～38mm 下方お よび38mm よりさらに下方の位置に存在することがわ かる．また，これらの位置は図 3 の粒子を用いた流れ の可視化結果とも良好に対応している.

以上の可視化結果により，強制対流の岐点の位置が 浮力の作用により平板下方へ移動することが明らかと なった. ここで, この岐点の移動がどのようなパラメ 一タに支配されているか明らかにすることは，工学的 に非常に重要と考えられる，そこで，上述の粒子およ び煙による可視化結果を基に，岐点が平板中央から下 方へ移動し始める条件を探ることにする．図５はその 結果を示したもので, 長さ $L=50,100 \mathrm{~mm}$ の平板につ

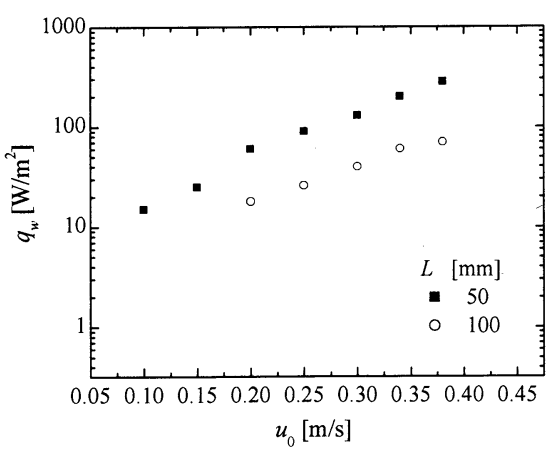

Fig. 5 The conditions for the shift of the stagnation points from the plate center
いて, 岐点が平板中心から下降し始める熱流束 $q_{w}$ を, 横軸に強制対流主流流速 $u_{0}$ をとってプロットしたも のである.この図から, 岐点が平板中央から下降を開 始する熱流束は主流速度 $u_{0}$ の増加に伴って急激に高 くなること, また同じ流速条件下では, 長さ $L=100 \mathrm{~mm}$ の方が $L=50 \mathrm{~mm}$ の平板よりも，より低い熱流束で岐 点が移動し始めることがわかる.

これらの結果から, 岐点の移動は $q_{w}, u_{0}$ および $L$ の 三つのパラメータにより支配されることが明らかとな った. そこで本研究では，つぎにこれらのパラメータ を基に平板長さ $L$ 基準の修正グラスホフ数 $G r_{L}{ }^{*}$ （= $\left.g \beta q_{w} L^{4} / \lambda \nu^{2}\right)$ およびレイノルズ数 $R e_{L}$ を求め, $G r_{L}{ }^{*}-R e_{L}$ 平面上に実験值をプロットし直してみた. その結果を 図6に示す.この図から, 実験值は平板長さ $L$ の如何 に依らず図中実線で示す一本の直線のまわりにまとま ることがわかる.この直線を式で表すと，以下のよう になる。

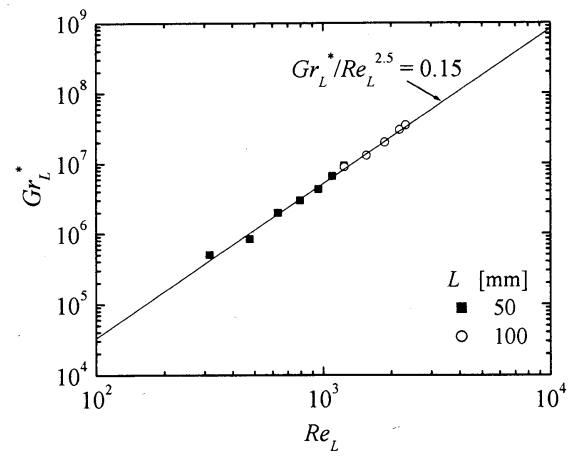

Fig. 6 Non-dimensional correlation for the shift of the stagnation points 


$$
G r_{L}^{*} / R e_{L}^{2.5}=0.15
$$

この直線より下の領域では, 岐点は平板中心に留まり， 上の領域では，平板中心よりも下方に岐点が存在する と言える.

$3 \cdot 2$ 伝熱特性 前節の流れの可視化結果から, 垂直加熱平板まわりの直交流共存対流場では, 浮力の 増加につれて岐点が平板の下方へ移動することが明ら かとなった．このような岐点の移動は，平板まわりの 伝熱特性に影響を及ぼすことが予想される，そこで本 研究では,つぎに平板の局所熱伝達率を測定すること により，伝熱面まわりの流動と伝熱特性との関係を調 べることにした.

この伝熱実験に先立ち，実験装置および測定の検定 を兼ねて, 強制対流および純自然対流下の局所熱伝達 率を測定してみた．そのうち強制対流下の局所熱伝達 率については，試験平板を弱く加熱し，比較的速い強 制対流気流中に置いた場合を対象に測定を行った。 そ の代表的な結果を, 長さ $L=100 \mathrm{~mm}$ の平板について, 図 7 に示す.この図は，平板中央から鉛直方向に距離 $x$ 離れた地点における局所熱伝達率 $h_{x}$ を測定し，その 結果を， $x$ を代表長さとする局所ヌッセルト数 $N u_{x}$ （= $\left.h_{x} x / \lambda\right)$ および局所レイノルズ数 $R_{x}\left(=u_{\infty} x / v\right)$ 平面上 にプロットしたものである. ここで局所レイノルズ数 の代表速度 $u_{\infty}$ は, 平板に沿うくさび流れ境界層の外縁 速度であり，以下の式(5)で与えられる。

$$
u_{\infty}=0.78 \frac{x}{L / 2} u_{0}
$$

図中の実線は，強制対流層流くさび流れに対する甲藤 ${ }^{(6)}$ の相似解を示している. なお，この相似解は次式で 表せる.

$$
N u_{x}=0.57 \operatorname{Pr}^{0.4} \operatorname{Re}_{x}^{1 / 2}
$$

ここで，上式の適用範囲はPr=0.5 5 である.この図 7 から明らかなように，本実験値は上述の解析解と良 好に一致していることがわかる. なお本実験では, こ の $L=100 \mathrm{~mm}$ の平板のみならず, 長さの異なる $L=50$, $150 \mathrm{~mm}$ の平板についても, 解析解と一致することを確 認している.

つぎに純自然対流下での平板まわりの局所熱伝達率 を測定してみた. その代表的な結果を図 8 に示す。こ の図は, $L=100 \mathrm{~mm}$ の平板について, 平板下端から距 離 $\xi$ 離れた地点における局所熱伝達率 $h_{\xi}$ を測定し, 縦 軸に平板下端から鉛直上方への距離 $\xi$ 代表長さにと った局所ヌッセルト数 $N u_{\xi}\left(=h_{\xi} \xi / \lambda\right)$ を，また横軸に 同じく $を$ 代表長さとする局所修正レイリ一数 $R a_{\xi}^{*}$ （= $\left.g \beta q_{w} \xi^{4} / \lambda v \alpha\right)$ をとり，実験值をプロットしたものであ る. 比較のため, 垂直な等熱流束加熱平板に沿う層流
自然対流に対寸る藤井 ${ }^{(7)}$ の相似解析解を図中実線で示 した. なお, 図中の実線は空気のプラントル数 $P r=0.72$ とおいたもので，このとき解析解は次式で表せる.

$$
N u_{\xi}=0.521 R a_{\xi}{ }^{* 1 / 5}
$$

この図 8 から明らかなように，本実験值はこの解析解 と良好に一致することがわかる．また，上と同様な結 果は $L=50$ および $150 \mathrm{~mm}$ の平板についても得られて いる.

以上の強制対流および純自然対流に対する実験結果 から，本装置および測定法は十分な精度を有すること が確認できた．そこで，つぎに本実験の主題である共 存対流下での局所伝熱特性と流動との関連を探ってい くことにする．まず，強制対流が支配的と考えられる 条件下で，平板まわりの局所熱伝達率の測定と流れの 可視化を行った結果を図 9 に示す。この図は長さ $L=$ $100 \mathrm{~mm}$ の平板を流速 $u_{0}=0.25 \mathrm{~m} / \mathrm{s}$ の気流に設置した場 合の結果を示したもので，図 9(a)に平板の局所熱伝達 率を，また図9(b), (c), (d)には，図9(a)と同じ加熱条件 下での可視化結果を掲げた．なお，局所熱伝達率は平 板中心からの距離 $x$ の関数として表しており, $x=0$ が 平板中心， $x=+50,-50 \mathrm{~mm}$ がそれぞれ平板上端および

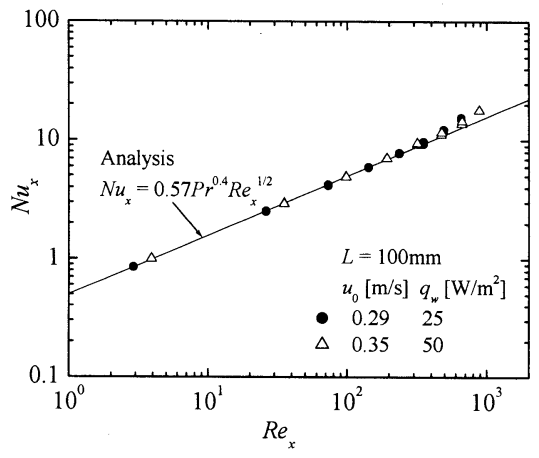

Fig. 7 Local Nusselt numbers of forced convection

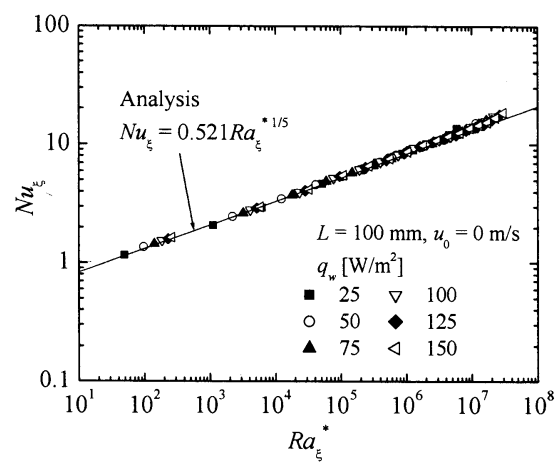

Fig. 8 Local Nusselt numbers of pure-natural convection 


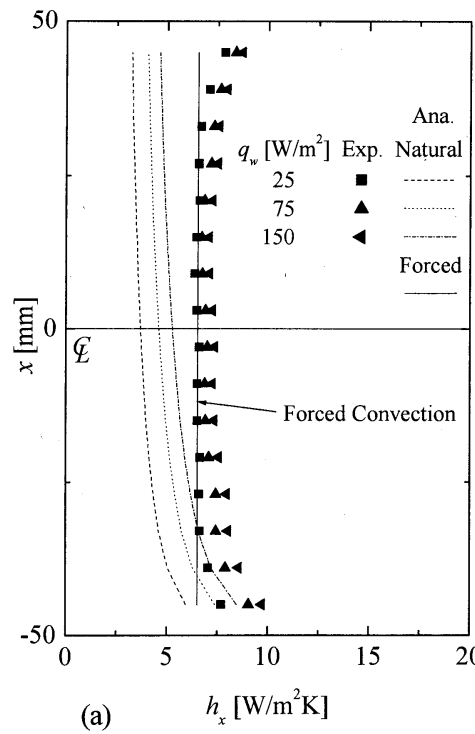

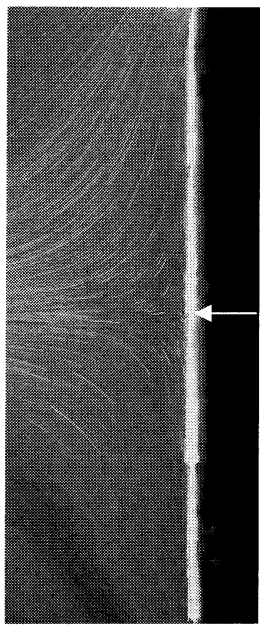

(b) $q_{w}=25 \mathrm{~W} / \mathrm{m}^{2}$

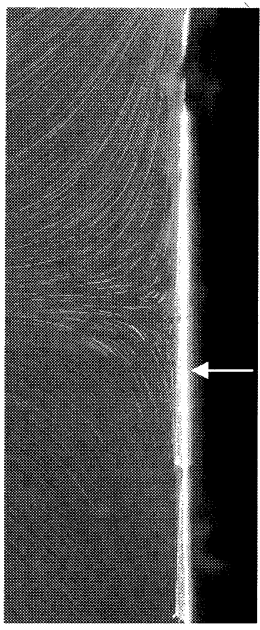

(c) $q_{w}=75 \mathrm{~W} / \mathrm{m}^{2}$

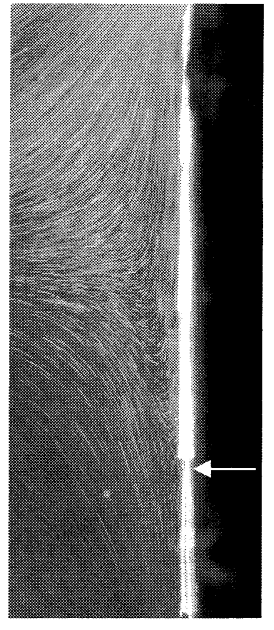

(d) $q_{w}=150 \mathrm{~W} / \mathrm{m}^{2}$

Fig. 9 Heat transfer characteristics and relevant flow fields for forced convection-dominated cases $\left(L=100 \mathrm{~mm}, u_{0}=0.25 \mathrm{~m} / \mathrm{s}\right)$. (a) Local heat transfer coefficients and (b)-(d) snapshots of visualized flow fields

下端に対応している. 図9(a)中には，比較のため式(5) から計算した強制対流層流くさび流れの局所熱伝達率 を実線で，また，各熱流束条件における層流純自然対 流の局所熱伝達率を式(6)により計算した結果を点線 で表した.

さて，熱流束が最も低い $q_{w}=25 \mathrm{~W} / \mathrm{m}^{2}$ の結果である が，まず図 9(b)から平板上の岐点は図中矢印で示寸平 板中央にあることが分かる．このとき平板の局所熱伝 達率は，図9(a)に示すように平板中心から $x= \pm 35 \mathrm{~mm}$ に至る広い範囲に亘って, 層流くさび流れの解析值に 一致していることが分かる. 一方, $x= \pm 40 \mathrm{~mm}$ 以降の 平板上下端部付近では, 本実験值は解析值よりも若干 高い值を示している. これは従来のくさび流れの解析 では無限長の平板上に層流境界層流れが発達するとの 仮定の下で相似解析が行われているが，本実験のよう な有限長さの平板では, 平板端部で流れの方向が急激 に変化するため, 端部付近での境界層内の速度分布に 相似則が成立しないことが理由として考えられる. 本 実験と同様な結果は五十嵐 ${ }^{(8)}$ によっても報告されてい る.つぎに熱流束を $q_{w}=75 \mathrm{~W} / \mathrm{m}^{2}$ 人増加させた場合で あるが，図 9(c)に示すように岐点は矢印の位置まで下 降する. このとき局所熱伝達率は, 図 9(a)に示すよう に平板全面に亘って $q_{w}=25 \mathrm{~W} / \mathrm{m}^{2}$ の值より高くなる. さらに熱流束を $q_{w}=150 \mathrm{~W} / \mathrm{m}^{2}$ に増加させると, 岐点は 平板下方一移動し (図 9(d)), 熱伝達率は単調に高く なっていく (図 9(a)) . また, とくに岐点近傍の局所 熱伝達率に注目すると, どの熱流束でもその分布は連
続的に変化しており, 岐点近傍で值が急激に変化する 様子は観察されなかった。 この結果は, 局所熱伝達率 が岐点を境に並行流域で強制対流值よりも上昇, 対向 流域で低下寸るとした Ramachandran ら ${ }^{(1)} の$ 解析結果と は明らかに異なっている。

ここまでは浮力が相対的に弱い条件下での結果であ ったが，逆に浮力が支配的な影響を及ぼす場合につい て, 平板まわりの伝熱と流動を調べた結果を図 10 に示 す. この図は, 長さ $L=100 \mathrm{~mm}$ の平板を流速 $u_{0}=$ $0.03 \mathrm{~m} / \mathrm{s}$ の気流中に設置した場合の結果を示したもの で, 図 10(a)に平板の局所熱伝達率を, また図 10(b), (c) に熱流束 $q_{w}=50$ および $150 \mathrm{~W} / \mathrm{m}^{2}$ の可視化結果を掲げ た.この条件下で最も熱流束の低い $q_{w}=50 \mathrm{~W} / \mathrm{m}^{2}$ でも， 既に岐点位置は図 10(b)中矢印で示す平板下端付近ま で移動している. このとき平板の局所熱伝達率は, 図 10(a)に実線で記した強制対流層流くさび流れの解析 值よりもかなり高い值を示し，その分布は，図中点線 で記した層流自然対流の解析值により近いことが分か る.さらに熱流束を $75,100,150 \mathrm{~W} / \mathrm{m}^{2}$ と増加させてい くと, 図 10(c)に示すように岐点は平板下端部へ到達し, 平板全体が鉛直上向きの自然対流で覆われるようにな る. また, これに伴って, 熱伝達率は平板全体に亘っ て単調に増加し, 自然対流の層流解析值へと漸近して w.

本実験では，これら一連の局所熱伝達率の測定と流 れの可視化を, 長さの異なる平板 $L=50$ および $150 \mathrm{~mm}$ についても試みている，その結果は上述した $L=$ 


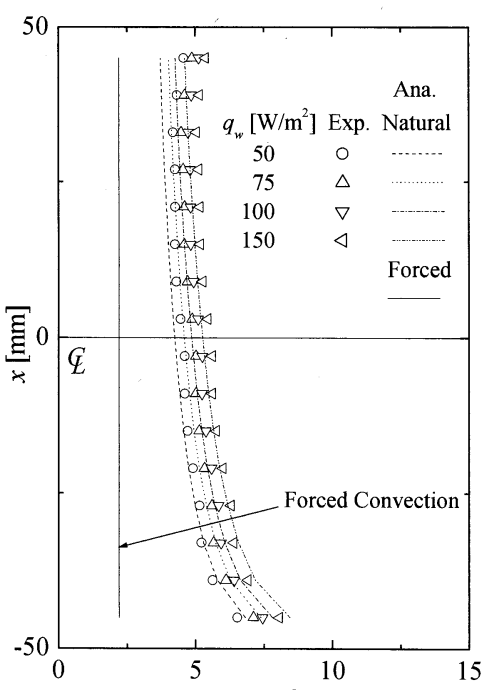

(a)

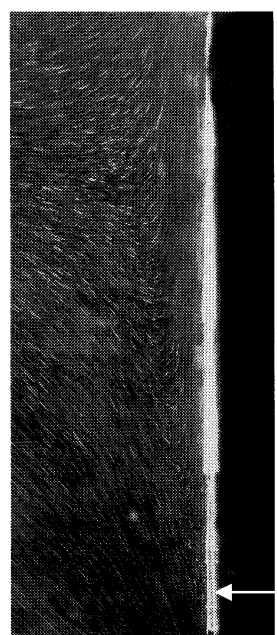

(b) $q_{w}=50 \mathrm{~W} / \mathrm{m}^{2}$

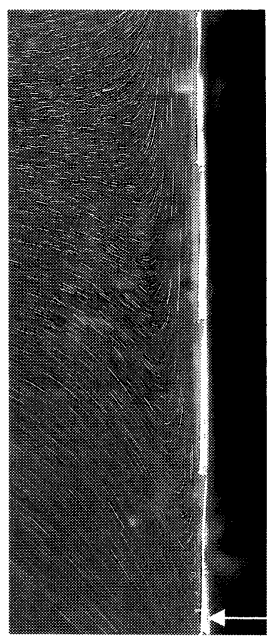

(c) $q_{w}=150 \mathrm{~W} / \mathrm{m}^{2}$

Fig. 10 Heat transfer characteristics and relevant flow fields for natural convection-dominated cases $\left(L=100 \mathrm{~mm}, u_{0}=0.03 \mathrm{~m} / \mathrm{s}\right)$. (a) Local heat transfer coefficients and (b), (c) snapshots of visualized flow fields

$100 \mathrm{~mm}$ の平板の結果と同様であり, 共存対流下の局所 熱伝達率は, 浮力の増加につれて強制対流層流くさび 流れの值から垂直加熱平板まわりの層流自然対流の值 へと単調に増加すること，また，平板上の流れの岐点 は平板下方へ移動していくが，岐点近傍の熱伝達率は 連続的であり特異的な変化は示さないことを確認して いる.

つぎに，本研究ではこれら局所熱伝達率の測定結果 を基に，平板まわりの平均熱伝達率を求め, 強制-共存 -自然対流各領域の判別を試みることにした. 前述の可 視化によれば，平板上の岐点の位置は，無次元パラメ 一夕 $G r_{L}{ }^{*} / \operatorname{Re}_{L}^{2.5}$ の值が 0.15 よりも大きくなると，平板 の中心から下方へ移動し始めることを確認している. また，図9に示した結果から，岐点が平板中心に留ま る条件下では，熱伝達率は強制対流くさび流れのそれ に一致し，浮力が増すにつれてくさび流れの值よりも 単調に高くなることを確認している. そこで，これら の結果を参考に, 本実験で得た平板の平均熱伝達率を, 上記無次元パラメータ $G r_{L}{ }^{*} / R_{L}{ }^{2.5}$ を用いて整理してみ た. 図 11 はその結果を示したもので，図の縦軸には， 実験で得られた平均熱伝達率 $h_{m}$ を，それと同じレイ， ルズ数 $R e_{L}$ および修正レイリ一数 $R a_{L}^{*}$ に対する強制お

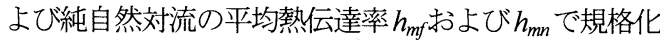
した熱伝達率比 $h_{m} / h_{m f}, h_{m} / h_{m n}$ をとり, 横軸には無次 元パラメータ $G r_{L}{ }^{*} / \operatorname{Re}_{L}{ }^{2.5}$ をとってプロットしたもので ある. この図から，本実験值は平板長さ $L$, 強制対流 流速 $u_{0}$ およひ熱流束 $q_{w}$ の如何に依らず，図中実線で
示す二本の曲線のまわりにまとまることが明らかであ る. 参考までに, これらの曲線を次式で近似し，

$$
\frac{h_{m}}{h_{m f}} \text { or } \frac{h_{m}}{h_{m n}}=1+c\left(\frac{G r_{L}^{*}}{R e_{L}^{2.5}}\right)^{n}
$$

実験值と最も良く一致する係数 $c$ および指数 $n$ を求め たところ，以下の式が得られた。

$$
\begin{aligned}
& \frac{h_{m}}{h_{m f}}=1+0.19\left(\frac{G r_{L}^{*}}{R e_{L}^{2.5}}\right)^{0.44} \\
& \frac{h_{m}}{h_{m n}}=1+0.26\left(\frac{G r_{L}^{*}}{R e_{L}^{2.5}}\right)^{-0.44}
\end{aligned}
$$

またこの図より, 無次元パラメータ $G r_{L}{ }^{*} / R e_{L}{ }^{2.5}$ の值が 0.1 以下の領域では, 平板の平均熱伝達率 $h_{m}$ は強制対 流層流くさび流れの平均熱伝達率 $h_{m f}$ に一致し, $G r_{L}{ }^{*} / \operatorname{Re}_{L}{ }^{2.5}$ の值が 20 以上の領域では， $h_{m}$ は層流自然対 流の平均熱伝達率 $h_{m n}$ に一致することが分かる. これ らの領域では，前述したように局所熱伝達率も強制お よび自然対流值にほぼ一致していることから，前者を 強制対流域, 後者を自然対流域とみなすことができる. 一方, 両者の中間の領域, $0.1<G r_{L}{ }^{*} / R e_{L}^{2.5}<20$ では, 平均熱伝達率 $h_{m}$ は強制および自然対流の平均熱伝達 率のいずれよりも高くなっている.この平均熱伝達率 が強制および自然対流值のいずれとも一致しない領域 を共存対流域と定義すると, 垂直加熱平板まわりの直 交流の共存対流域は, $0.1<G r_{L}{ }^{*} / R e_{L}{ }^{2.5}<20$ の領域に相 


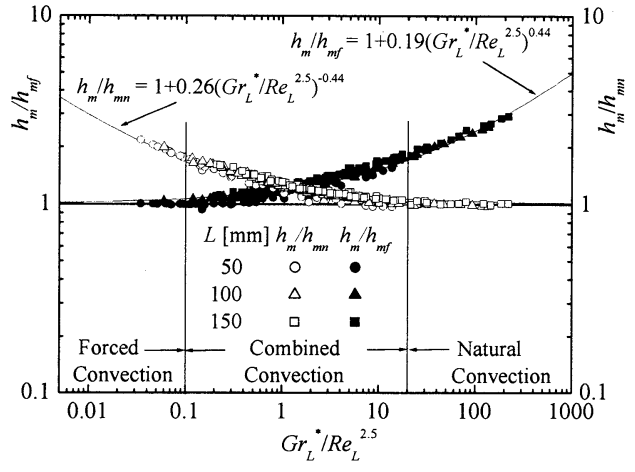

Fig. 11 Normalized average heat transfer coefficients

当すると言える. このうち強制対流と共存対流の閾值 $G r_{L}{ }^{*} / \operatorname{Re}_{L}{ }^{2.5}=0.1$ は，流れの可視化で明らかにした岐点 が平板中心から下方に移動し始める条件 $G r_{L}{ }^{*} / R_{L}{ }^{2.5}=$ 0.15 とほぼ一致している.この結果は, 岐点の移動に 伴って平板の伝熱特性が強制対流のそれから変移し始 めることを意味しており, 重要かつ興味深い結果と言 える. このように，平板まわりの流れの可視化および 熱伝達率の測定結果を基に, 垂直な加熱平板まわりの 直交流共存対流の領域判別を行った例は本研究の他に 無く, 本研究で得られた一連の成果は, CVD 成膜問題 を始めとする様々な機器の熱設計を行うための基礎資 料として, また今後試みられるであろう数值解析の検 証用データベースとして活用されるものと考える.

\section{4. 結 言}

本研究では，一様な流速で水平に流れる気流中に, 有限な大きさの加熱平板を流れに直交して垂直に設置 した場合について，平板まわりに生じる直交流共存対 流の流動と伝熱を可視化および伝熱実験により探った. 試験流体には常温の空気を用い，この気流が衝突する 平板表面を等熱流束条件で加熱した. 実験は平板まわ りの流れが強制および純自然対流時に層流とみなせる, 平板長さ $L$ 基準のレイノルズ数 $R e_{L}$ および修正レイリ 一数 $R a_{L}{ }^{*}$ が，それぞれ $160<R e_{L}<2300,4.3 \times 10^{5}<R a_{L}{ }^{*}$ $<2.0 \times 10^{8}$ の範囲で行った.

まず平板まわりに生じる流動状況を浮遊粒子および 煙をトレーサとした可視化により探った. その結果, 以下の知見が得られた。

(1) 平板に衝突する流れの岐点は, 浮力が小さな場 合には平板中央に位置するが, 浮力がある值以上にな ると平板の中央から下方へと移動し始め, さらに浮力 が増加すると平板下端部へ到達し, 平板全体が鉛直上 向きの自然対流で覆われるようになる.
（2）上述した岐点が平板中央から移動し始める条件 は, 無次元パラメータ $G r_{L}^{*} / R e_{L}^{2.5}$ によって規定でき,

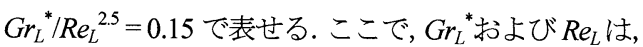
平板長さ $L$, 気流流速 $u_{0}$, 熱流束 $q_{w}$ をそれぞれ代表長 さ，速度および熱流束とする修正グラスホフ数 $G r_{L}{ }^{*}$ お よ゙゙レイノルズ数 $R_{L}$ である.

つぎに平板の局所および平均熱伝達率を測定した。 その結果, 以下の知見が得られた.

(3) 平板の局所熱伝達率は, 浮力が弱い場合には強 制対流層流くさび流れの值に一致する．また，その值 は浮力の増加とともに高くなり, 浮力が十分強くなる と, 垂直加熱平板まわりの層流自然対流の值に一致す る. また，その分布は岐点近傍で連続であり，岐点の 移動に伴う特異的な変化は見られなかった.

(4) 平板の平均熱伝達率は, 上述の無次元パラメー タ $G r_{L}{ }^{*} / R e_{L}{ }^{2.5}$ により整理でき, とくに $0.1<G r_{L}{ }^{*} / \operatorname{Re}_{L}{ }^{2.5}$ お よび $G r_{L}{ }^{*} / \operatorname{Re}_{L}{ }^{2.5}>20$ の領域での平均熱伝達率は, それ ぞれ強制および自然対流の平均熱伝達率に一致する. 一方, この中間の領域, $0.1<G r_{L}{ }^{*} / R e_{L}{ }^{2.5}<20$ では, 強 制および自然対流のいずれの值よりも高くなる.

(5)この結果から, 垂直加熱平板まわりの直交流共 存対流域は, $0.1<G r_{L}{ }^{*} / R e_{L}{ }^{2.5}<20$ で表せることが分か った.

\section{文 献}

(1) Ramachandran, N., Chen, T. S. and Armaly, B. F., Mixed Convection in Stagnation Flows Adjacent to Vertical Surfaces, Transactions of ASME, Journal of Heat Transfer, Vol.110, No.2 (1988), pp.373-377.

(2) Biswas, G., Laschefski, H. Mitra, N.K. and Fiebig, M., Numerical Investigation of Mixed Convection Heat Transfer in a Channel with a Built-in Square Cylinder, Numerical Heat Transfer, Part A., Vol. 18 (1990), pp.173-188.

(3) Turki, S. Abbassi, H. and Nasrallah, S.B., Two-Dimensional Laminar Fluid Flow and Heat Transfer in a Channel with a Built-in Heated Square Cylinder, International Journal of Thermal Sciences, Vol.42 (2003), pp.1105-1113.

(4) Dhiman, A. K., Chhabra, R. P. and Eswaran, V., Steady Mixed Convection Across a Confined Square Cylinder, International Communications in Heat and Mass Transfer, Vol.35 (2008), pp.47-55.

(5) The Japan Society of Mechanical Engineers ed., JSME Data Book: Heat Transfer, (1986), p.62, The Japan Society of Mechanical Engineers.

(6) Katto, Y., Outline of Heat Transfer (in Japanese), (1977), p.71, Yokendo Ltd.

(7) Fujii, T., Advances in Heat Transfer, Vol.3, (1974), p.34, Yokendo Ltd.

(8) Igarashi, T., Fluid Flow and Heat Transfer around a Square Prism, Transactions of the Japan Society of Mechancal Engineers, Series B, 50-452 (1984), pp.1173-1181. 